\title{
Jak učitelé německého jazyka užívají ve výuce angličtinu ${ }^{1}$
}

\author{
Miroslav Janík \\ Institut výzkumu školního vzdělávání, Pedagogická fakulta, Masarykova univerzita
}

Redakci zasláno 21.12. 2016 / upravená verze obdržena 8. 3. 2017 /

k uveřejnění přijato 10.3. 2017

\begin{abstract}
Abstrakt: V předkládané studii jsme se zaměřili na užívání angličtiny učiteli ve výuce němčiny jako dalšího cizího jazyka (po angličtině). $V$ teoretické části je představeno naše chápání jazyka a jazykového jednání ve vztahu k mnohojazyčnosti a jazykové politice. V této studii pojímáme jazyky ve smyslu jazykových repertoárů, mnohojazyčnost pak jako schopnost užívat (na různé úrovni) tři a více jazyků. Pod pojmem jazyková politika (policy) rozumíme jak procesy státní politiky („top-down“), které mají tendenci podporovat aditivní pojetí mnohojazyčnosti, tak procesy jazykové politiky ve školní třídě („bottom-up“), která je založena na jazykovém jednání (především učitelů) a zahrnuje (mimo jiné) legitimizaci jazyků prostřednictvím jejich užívání. Hlavní výzkumná otázka byla stanovena: Jak jsou organizovány situace ve výuce německého jazyka, ve kterých učitel užívá anglický jazyk? Výzkumný vzorek tvoří 28 videonahrávek hodin německého jazyka na druhém stupni základní školy a jejich transkripty. Před představením metody analýzy - konverzační analýzy - a jejím teoretickým ukotvením je popsána jednotka analýzy - výuková situace - a postup, jak jsme ji identifikovali. V následující části studie jsou prezentovány výsledky. Z hlediska struktury byla v identifikovaných situacích patrná struktura iniciace-odpověd'-zpětná vazba (IRF) v různých modifikacích. $\mathrm{Z}$ analýzy vyplývá, že učitelem užitá angličtina je patrná ve výuce německého jazyka v komentářích a nápovědách. Pokud byla angličtina užita v komentáři, pak se často jednalo o rozširrení zpětné vazby na předešlou žákovu odpověd, nebo komentář sloužil jako výklad, ve kterém bylo podporováno metalingvistické povědomí. Nápovědy, ve kterých byl patrný anglický jazyk, byly užity jako reakce na problém či chybu (často nesouvisející s angličtinou) v žákově odpovědi. $\mathrm{V}$ takovém případě byla $\mathrm{v}$ nápovědách přítomna metalingvistická vodítka, která měla vést žáky k sebeopravě. Z výsledků studie sice vyplývá, že užívání anglického jazyka je přirozeným jazykovým jednáním učitelů, které má vést k rozvoji německého jazyka, ale nebylo možné identifikovat ucelený přístup učitelů k užívání anglického jazyka a k podpoře mnohojazyčnosti.
\end{abstract}

Klíčová slova: mnohojazyčnost, jazykový repertoár, jazykové jednání, jazyková politika, oborová didaktika, výuka německého jazyka po angličtině, konverzační analýza, interakce, struktura IRF

1 Tato studie vznikla v rámci projektu Výzkum učení a vyučování cizím jazykům (MUNI/ A/1277/2016). 
Vzhledem ke společenskému i hospodářskému vývoji u nás i v celé Evropě je zřejmé, že význam jazyků a jazykového vzdělávání roste. $V$ dokumentech Evropské unie se setkáváme s požadavkem, aby každý Evropan hovořil alespoň dvěma cizími jazyky (např. Vzdělávání..., 2008). V České republice je od roku 2013 (Rámcový..., 2013, s. 27) kurikulárně podporována (resp. př́imo nařízena) výuka minimálně dvou cizích jazyků již od primárního (nejpozději však od nižšího sekundárního) stupně vzdělávání. ${ }^{2}$

Nástroje unijní i české státní jazykové politiky (ve směru „top-down“), které představují i kurikulární dokumenty, pojímají jazyky jako separátní entity, jež jsou často zastoupeny jednotlivými předměty ${ }^{3}$ a směřují k tzv. aditivní mnohojazyčnosti (viz dále). Naproti tomu ve výuce (nejen) cizích jazyků (a mimo ni) se zachází s jazyky kreativně, jsou užívány „,volně“, často bez ohledu na „klasické“ jazykové normy ${ }^{4}$ - a to jak na straně žáků, tak na straně učitelů, kteří s jazyky žáků (popř. svými) operují (a zároveň utvářejí jazykovou politiku směrem „bottom-up“).

V této studii budeme sledovat, jak je ve výuce využíváno více jazyků (resp. jazykových repertoárů, viz dále) ze strany učitelů. $V$ centru naší pozornosti nebude míšení dvou separátních ${ }^{5}$ jazykových kódů, ale jazykové jednání. Zaměříme se na takové učitelovo jazykové jednání ve výukových situacích ve školní výuce němčiny, ve kterých užívá anglický jazyk (jejž se žáci učili dříve během školního vzdělávání, viz Rámcový..., 2013). Cílem tohoto textu je nejen popsat vybrané výukové situace, ale také poukázat na to, že jazyky užívané v cizojazyčné výuce nemají povahu autonomních entit, jak jsou pojímány v kurikulárních dokumentech, ale že je učitelé užívají ve vzájemné souvislosti.

2 Stěžejní kurikulární dokument pro nižší sekundární stupeň vzdělávání v České republice Rámcový vzdělávací program pro základní vzdělávání (dále RVP ZV) - doporučuje, aby jako první cizí jazyk byla nabízena angličtina. Další cizí jazyky (mj. i německý jazyk) se obvykle dostávají do pozice tzv. dalšího cizího jazyka. Jde tedy o (jazykově) politické a ideologické rozhodnutí.

3 Mnozí autoři (např. García, 2014) připisují tento stav snaze o standardizaci výstupů v cílovém jazyce a tlaku na měřitelné výsledky žáků.

4 Tím myslíme normy jazykové „správnosti“, např. v češtině hovoříme o pravidlech českého pravopisu.

5 Pojmem separátní chceme zdůraznit oddělené chápání jazyků (tj. zvlášt' čeština, němčina, angličtina) v kontrastu s pojetím jazykového repertoáru (viz dále), který chápe jazyky jako navzájem propojené entity, které jsou situačně užívány. 


\section{Teoretické ukotvení: jazyky a mnohojazyčnost}

Na nejobecnější úrovni vycházíme v této studii z premisy, že žádný člověk není jednojazyčný (např. Busch, 2012a). Předpokládáme tak, že žáci si přinášejí do výuky svůj jazykový repertoár, který se skládá z různých (mnohdy částečně ovládaných) jazyků, dialektů či stylů (srov. Blommaert, 2010), jež si osvojili v různých kontextech - tedy i ve škole. Jazyky tedy chápeme ve smyslu jazykového repertoáru (verbal repertoire, viz Gumperz, 1964; někdy označovaný i jako linguistic repertoire, viz Busch, 2012b). Jazykový repertoár lze chápat jako „arzenál“ pro každodenní komunikaci, ze kterého si mluvčí vybírá komunikační „zbraň“ podle toho, co chce sdělit (Gumperz, 1964, s. 137). ${ }^{6}$ Zjednodušeně řečeno, jazykový repertoár zahrnuje všechny druhy vyjádření, v jejichž důsledku dochází ke vzájemnému porozumění.

Je patrné, že na jazyky v této studii není nahlíženo jako na nezávislý soubor předem daných pravidel či struktur (viz např. de Saussure či Chomsky), ale spíše jako na „reakce na diskursivní potřebu“ (Bybee \& Hopper, 2001, s. 3). Z tohoto pohledu je možné jazyk chápat jako akt sociálního jednání, v jehož rámci se více než na (relativně statické) struktury (tj. na gramatiku, syntax) zaměřujeme na jeho dynamické sociální užití. V zahraniční odborné literatuře se v tomto kontextu hovoří o languaging (např. Swain et al., 2009) či o translanguaging (viz dále), které zdůrazňují dynamičnost a procesuálnost jazyka a jež lze charakterizovat jako procesy tvorby významu a zkušenosti, utváření porozumění a znalostí pomocí jazyků. Jazyky jsou užívány dynamickým a funkčním způsobem tak, aby došlo k rozvoji procesů porozumění, komunikace a v neposlední řadě také k učení se (Lewis, Jones, \& Baker, 2012, s. 641).

V této studii se zaměřujeme především na jazykové, resp. mnohojazyčné jednání (z angl. practice). Mnohojazyčné jednání zde nechápeme jako užití jazyků jakožto dvou separátních jednotek nebo jako míšení dvou separátních kódů, ale užití jazykových repertoárů je realizováno v daném situačním kontextu (srov. Kloss \& Van Orden, 2009). Vycházíme tak z přesvědčení, že jazyky nejsou na sobě nezávislé (viz García, 2014), ale že mezi nimi existuje vztah, který je patrný právě v jazykovém jednání.

6 To sice znamená, že mluvčí má absolutní svobodu ve vyjádření, ale existují společenské a gramatické restrikce, které umožňují vzájemné porozumění a akceptaci promluv. Jinak řečeno, každá promluva by měla být konformní vůči gramatickým restrikcím, avšak interpretována je až na základě sociálního jednání (Gumperz, 1964, s. 137-138). 
V odborné literatuře lze nalézt různé přístupy a související pojmy, které se používají ve výzkumu jazyků a mnohojazyčnosti ve smyslu jazykového jednání. Např́íklad García (2009) užívá již zmíněné označení translanguaging, Canagarajah (2012) pojmu translingual practice. Dále např́klad Buschová (2014) používá pojem heteroglossia (vycházející z prací Bachtina), jenž odkazuje nejen na diversitu jazykového kódu, ale také na to, že mluvčí pomocí jazyka vyjadřuje svoji pozici (ve smyslu positioning) ke společenskému diskursu a $\mathrm{k}$ jazykové formě. Ty pak odkazují k různým sociálním prostorům a kulturně-historickým událostem. Jørgensen (2008) odkazuje na kombinace vlastností jazyka, které nejsou diskrétní ani kompletní, a užívá termínu polylingualism. Jacquemet (2005) hovoří o transidiomatic practices a zaměřuje se na užívání různých jazykových kódů, které jsou simultánně přítomné v různých lokalitách. Otsuji a Pennycook (2010) zkoumají fluidní povahu jazykového jednání v urbánních oblastech a užívají termín metrolingualism. $\mathrm{V}$ této studii nebudeme diferencovat mezi zmíněnými zaměřeními a zůstaneme na úrovni mnohojazyčného jednání, jež chápeme jako (víceméně) pro ně nadřazený pojem.

Pod samotným pojmem mnohojazyčnost ${ }^{7}$ rozumíme takovou vlastnost jedin$\mathrm{ce}^{8}$, jež mu umožňuje užívání jazyků (resp. jazykové repertoáry) v konkrétních komunikačních situacích k dosažení komunikačních cílů (srov. Krumm, 2003, s. 36). V tomto pojetí je rozvoj mnohojazyčnosti závislý nejen na lingvistických, ale také na sociokulturních, politických, historických a jiných faktorech.

V kontextu školního vzdělávání obecně se lze mnohojazyčností výzkumně zabývat (dle Vetter, 2013) na třech úrovních: (a) uznání (ve smyslu recognition) jazyků a jazykových repertoárů (sem lze řadit studie zaměřené na jazykovou politiku škol, národní jazykové strategie, hidden agenda aj.; např. Krzyzanowski \& Wodak, 2011; Johnson, 2010); (b) jazyky, které jsou užívané ve škole a ve výuce (studie orientované na jazykové jednání - ve smyslu

7 Konceptualizací mnohojazyčnosti v kontextu výuky cizích jazyků jsme se zabývali dříve (např. Janík, 2013).

8 V této studii se soustředíme pouze na mnohojazyčnost na individuální úrovni, avšak lze se jí zabývat i na společenské úrovni - obecně se dá totiž mnohojazyčnost chápat jako fenomén společenský a individuální. Zatímco pod pojmem společenská mnohojazyčnost lze rozumět jazykové bohatství společensko-politického seskupení, individuální mnohojazyčnost je chápána jako jazykové bohatství jedince (srov. Kemmeter, 1999, s. 53).

9 Pod pojmem hidden agenda rozumíme jazykové jednání, které je tzv. skryté - jde o jazykové jednání, které se odehrává ve školách, ale není opřeno o kurikulum či o jakoukoliv školní podporu či evidenci. Často jde o jazykové jednání žáků, kteří hovoří lépe jiným jazykem, než je vyučovací jazyk, a to „skrytě“, mezi sebou, během výuky či o přestávkách. 
practice, školní jazyk, translanguaging ve výuce aj.; např. Blackledge \& Creese, 2009; Bonacina-Pugh, 2012; Makalela, 2015); (c) cizí a tzv. druhé jazyky, ${ }^{10}$ jejich osvojování a výuka (např. Henry \& Apelgren, 2008; Dewaele \& Thirtle, 2009). ${ }^{11}$

V této studii se zaměříme na jazykové (resp. mnohojazyčné) jednání ve výuce cizích jazyků. Jazykové jednání ve školní výuce je ovlivněno (mimo jiné) jazykovou politikou - nejedná se však pouze o to, které jazyky a v jakém didaktickém postavení vůči sobě budou vyučovány, ale také jaké jazyky budou ve výuce užívány a kdy. $\mathrm{V}$ následující kapitole se proto budeme zabývat vymezením a pojetím jazykové politiky.

\section{Jazyková politika, kurikulum a jazykové jednání}

Jazyková politika (language policy, Sprachpolitik) je pojmem, který zahrnuje řadu procesů a nejčastěji bývá spojován s výkonem státní moci (pomocí zákonů, nařízení, předpisů...), která reguluje užívání jazyků a vztahy mezi nimi. ${ }^{12}$ V oborovědidaktickém výzkumu orientovaném na (cizí) jazyky je jazyková politika spojována spíše s oblastmi jazykového plánování (např. Coulmas, 1985) a jazykových ideologií (např. Woolard, 1992). Přenesení pojmu jazykové politiky do oborovědidaktického kontextu s sebou nese i jeho rozšíření - na jazykovou politiku lze nahlížet jako na jakékoliv otevřené ovlivňování komunikačního okruhu jazyků (Busch in Christ, 1995, s. 75). Jazyková politika v takovém pojetí zahrnuje nejen procesy „top-down“, reprezentované především kurikulem, ale také „bottom-up“ procesy, vycházející mj. z reálného jazykového jednání ve výuce.

Přístupy kurikulárních dokumentů ohledně cizích jazyků vycházejí často z předpokladu, že jazyky by měly být užívány, a tedy i vyučovány izolovaně jeden od druhého (srov. García, 2014, s. 93). ${ }^{13} \mathrm{~V}$ tomto př́padě lze hovořit

10 Rozdílům mezi cizími a druhými jazyky jsme se věnovali podrobně v Janík (2013).

11 Bližší popis zmíněných úrovní viz Vetter (2013).

12 Někteří autoři $\mathrm{v}$ souvislosti $\mathrm{s}$ jazykovou politikou hovoří o jazykovém managementu (např. Neustupný \& Nekvapil, 2003).

13 Mnoho autorů (García, 2014) připisuje snahu o podporu aditivní mnohojazyčnosti tlaku vzdělávacích politik („top-down“) na standardizaci výstupů výuky cizích jazyk a na relativně malý zájem o procesy odehrávající se v reálné výuce. Jiníautoři spojujíaditivní mnohojazyčnost se snahou podporovat „elitní“ jazyky (Krumm, 2015), které představují určitý (zejména však ekonomický či společenský) potenciál. $\mathrm{V}$ důsledku toho jsou pak jazykům dány „mantinely“ jejich užívání a vzniká představa, že si jazyky navzájem „konkurují“, a proto by legitimizace dalších jazyků ve výuce mohla přinést ohrožení jejich zastoupení v kurikulu. 
spíše o aditivním pojetí učení se cizím jazykům ve výuce - někteří autoři pak zavádějí pojem aditivní mnohojazyčnosti ${ }^{14}$ (např. Jakisch, 2014). Jiní autoři v této souvislosti popisují jazyky jako „dva a více solitéry“ (Cummins, 2007). Tento přístup je navíc zakotven jak v evropských tak v národních kurikulárních dokumentech ${ }^{15}$ (viz Vzdělávání..., 2008; Rámcový..., 2013 ${ }^{16}$ ).

Zatímco kurikulární dokumenty a dokumenty jazykové politiky tedy směřují k aditivní mnohojazyčnosti (srov. García, 2014, s. 95), reálné užívání jazyků má mnohdy zcela odlišný charakter. Ve výukové praxi jsou totiž jazyky užívány flexibilně - v některých př́ípadech jsou jazyky užívány náhodně, mnohdy dochází k záměrnému užití více jazyků (srov. García, 2014, s. 93). Nejen „hlas praxe“, ale i mnozí výzkumníci kritizují striktní politiku jazykového oddělování a přesvědčení, že jen „cílový“ jazyk může být užíván ve výuce (např. Cummins, 2007; Fitts, 2009; García, 2009).

Na reálné užívání jiného jazyka než je „cílový“ jazyk ve výuce se zaměřuje tato studie. Velká část autorů se sice zaměřuje na užívání jazyků žáky (viz např. Hall \& Cook, 2012), v této studii se ale v prvé řadě zaměřujeme na mnohojazyčné jednání učitele. $\mathrm{Z}$ tohoto důvodu se budeme $\mathrm{v}$ následující kapitole zabývat právě učitelem a specifiky jeho role ve výuce (dalšího) cizího jazyka.

\subsection{Učitel a jeho jazykové jednání}

Předpokládáme, že nejen žáci, ale i učitelé užívají ve výuce svůj jazykový repertoár. ${ }^{17}$ Navíc učitelé mohou užívat repertoár žáků, takže lze

14 V souvislosti s kurikulem je ve shodě s terminologií užívanou Radou Evropy a Evropskou komisí užíván pojem plurilingvismus (u nás překládán jako vícejazyčnost). Ten je přítomný zejména v diskursu vzdělávací politiky a administrativy (např. Sladkovská \& Šmídová, nd.). Protože perspektiva plurilingvismu je charakterizována chápáním jazyků jako oddělených a na sobě nezávislých entit, lze plurilingvismus chápat ve smyslu aditivního pojetí mnohojazyčnosti.

15 V zahraniční literatuře lze však nalézt i návrhy společného jazykového kurikula, např. Hufeisen (2011).

16 Pro úplnost dodejme, že v RVP ZV se v oblasti týkající se jazyků o mnohojazyčnosti hovoří, a to $\mathrm{v}$ rámci obecné charakterizace oblasti. Jedním z cílů jazykového vzdělávání by mělo být dle tohoto dokumentu „rozvíjení pozitivního vztahu k mnohojazyčnosti a respektování kulturní rozmanitosti“ (Rámcový..., 2013, s. 17). Více se zde však o mnohojazyčnosti nehovoří, takže na pojetí aditivní mnohojazyčnosti usuzujeme z obecné povahy tohoto dokumentu v části cizích (a dalších cizích) jazyků.

17 Vycházíme nejen z toho, že se takřka v celé Evropě žáci učí alespoň dva cizí jazyky a že učitelé hovoří více jazyky, ale i že na obecné úrovni lze hovořit o velké jazykové rozmanitosti v důsledku migrace. V České republice se mnohojazyčností zabývali např. Nekvapil a kol. (2009). 
na učitele (vzhledem $\mathrm{k}$ jeho institucionálnímu postavení ve třídě) nahlížet jako na představitele a aktéra jazykové politiky (ve smyslu policy) ve směru „bottom-up“. Učitelova role jako představitele jazykové politiky souvisí s procesem tzv. přizpůsobování výuky (appropriation; např. Levinson et al., 2009). Přizpůsobováním výuky míníme, že aktéři (žáci i učitel) kreativně interpretují elementy jazykové politiky (u nás zejména RVP ZV a ŠVP) a vnášejí je do diskursivních praktik (srov. Brown, 2010, s. 300). Tato interpretace „top-down“ jazykové politiky, interakce a učitelovo přesvědčení vytvářejí prostor pro tvorbu vlastní jazykové politiky ve výuce (tj. „bottom-up“). Učitel jako aktér jazykové politiky ve školní třídě má možnost legitimizovat jazyky, přičemž tato politika je realizována v interakci (viz např. Amir \& Musk, 2013). ${ }^{18}$ Dále také učitelé $v$ této roli reprodukují a zároveň spoluutváří jazykové ideologie, podle kterých se „ř́ídí jazykové jednání ve školní třídě (Brown, 2010, s. 298).

Nahlédneme-li stav výzkumu mnohojazyčného jednání učitele, není tato oblast př́liš zmapována (přinejmenším v porovnání $\mathrm{s}$ výzkumem jazykového jednání žáků). Z metaanalýzy Palmerové a Martinéze (2016) vyplývá, že velká část výzkumů se zabývá (1) postoji učitelů vůči jazykům a „odrazu“ těchto postojů v jednání a (2) evaluací výukových (obvykle oborově nespecifických) programů, jež jsou jazykově citlivé a mají rozvíjet mnohojazyčnost, a procesy jazykového jednání, které se v těchto programech odehrávají.

Protože jazykové jednání učitele v rámci „běžné“ výuky cizích jazyků není ve výzkumu prŕliš reflektováno, stalo se tématem této studie. ${ }^{19}$ Navíc odborné publikace, které se jazykovému jednání věnují, bývají spíše orientovány lingvisticky, popř aplikovaně lingvisticky (ve vztahu k jazykové politice ve výuce viz např. Bonacina-Pugh, 2012). Tato studie se však snaží přinášet i oborovědidaktický pohled. Nyní tedy přejděme k popisu metodologie vlastního výzkumu.

\section{Metodologie výzkumu}

V následující kapitole představíme design výzkumu: cíle a výzkumné otázky, metody sběru dat a charakteristiku výzkumného vzorku, poté

18 V kontextu interakce ve školní třídě se nejčastěji hovoří (např. Levinson et al., 2009) o procesech vyjednávání (negotiation) a rezistence (resistence) vůči jazykové politice (policy).

19 Pro úplnost dodejme, že se budeme zabývat situacemi z výuky německého jazyka, ve kterých učitel užívá anglický jazyk. 
popíšeme jednotku analýzy - výukovou situaci - nastíníme východiska konverzační analýzy, která byla využita pro analýzu, a na závěr představíme metodologický postup.

\subsection{Cíle výzkumu a výzkumná otázka}

Cílem studie je popsat situace z reálné výuky německého jazyka na druhém stupni základní školy, v nichž učitel užívá anglický jazyk. Výzkumná otázka byla stanovena takto: Jak jsou organizovány situace ve výuce německého jazyka, ve kterých učitel užívá anglický jazyk?

\subsection{Sběr dat, výběr vzorku a jeho charakteristiky}

Pro tuto studii jsme využili dat získaných v rámci projektu IVŠV Videostudie německého jazyka. ${ }^{20}$ Sběr dat probíhal $\mathrm{v}$ období od února do června roku 2012 a bylo pořízeno 28 videozáznamů výuky německého jazyka na druhém stupni základní školy. Nahrávány byly čtyři vyučovací hodiny u sedmi učitelů a k videonahrávkám byly získány také kontextuální údaje. ${ }^{21}$ Ve výuce všech nahrávaných tříd byl německý jazyk vyučován jako další cizí jazyk po angličtině.

Z technických důvodů jsme se zaměřili pouze na základní školy v Jihomoravském kraji. Původní snahu o náhodný výběr nebylo možné z důvodu odmítání škol realizovat, jedná se tedy spíše o vzorek dostupný. ${ }^{22}$

20 IVŠV videostudie německého jazyka navazuje na IVŠV videostudie, které v minulých letech proběhly ve výuce fyziky, zeměpisu, tělesné výchovy, anglického jazyka a ve výuce na prvním stupni základní školy (viz Najvar et al., 2011). Projekt IVŠV videostudie je inspirován zahraničními studiemi, jako například videostudií matematiky a přírodních věd TIMSS 1995, 1999 (Hiebert et al., 2003), švýcarskou videostudií kvality výuky matematiky (Reusser \& Pauli, 2003) či videostudií v rámci projektu DESI (Klieme et al., 2006), která zkoumala kvalitu výuky angličtiny v Německu.

21 Vlastní nahrávání vyučovacích hodin probíhalo vždy po předchozí domluvě s učiteli. Protože jsme chtěli zachytit reálnou výuku německého jazyka, nebyly kladeny na učitele žádné požadavky týkající se průběhu či obsahu nahrávaných hodin. Videozáznamy hodin byly pořízeny standardizovaným způsobem pomocí dvou kamer, první kamera byla namířena na žáky a druhá kamera na učitele (viz Najvar et al., 2011). Před vlastním nahráváním byly získány souhlasy rodičů s natáčením žáků ve výuce a souhlasy zúčastněných učitelů.

22 Výběr škol probíhal následujícím způsobem: pomocí generátoru náhodných čísel (v programu Statistica 7.1) jsme vybrali 70 škol. K výběru jsme užili náhodného váženého výběru, aby bylo dosaženo poměru městských a mimoměstských škol (poměr $5: 1$ byl převzat z IVŠV videostudií, viz Najvar et al., 2011; Zlatníček, 2015). U vybraných škol jsme zjišt’ovali, zda na nich probíhá výuka německého jazyka v osmých a devátých ročnících. Poté jsme oslo- 
Celkově jsme totiž oslovili 40 škol, ke spolupráci jsme získali 7 škol. Na každé škole s námi spolupracoval jeden učitel. ${ }^{23}$

Průměrná délka praxe byla u učitelů 9 let, přičemž nejdelší praxe činila 20 let a nejkratší 2 roky. Všichni učitelé uvedli v dotazníku jako nejvyšší dosažené vzdělání vysokoškolské. Šest učitelů mělo aprobaci pro německý jazyk pro ZŠ, pouze jeden učitel měl aprobaci na výtvarnou výchovu a speciální pedagogiku (potřebné vzdělání pro výuku německého jazyka si v době výzkumu doplňoval). Všichni učitelé také ovládali anglický jazyk - jejich úroveň se dle vlastního hodnocení pohybuje mezi A2 a B2 dle Společného evropského referenčního rámce pro jazyky (2002). Žákovskou znalost anglického jazyka pak usuzujeme pouze z rozhovorů se všemi učiteli (ve kterém uvedli, že se žáci učili německý jazyk po anglickém jazyce). Úroveň žákovských znalostí německého jazyka nebyla z technických důvodů zjišt'ována, ve škole se žáci učí němčině 1 a 3 roky, přičemž výstupní úroveň (v době sběru dat stanovená v RVP ZV, 2007) měla odpovídat přibližně A1 dle Společného evropského referenčního rámce pro jazyky (2002).

\subsection{Jednotka analýzy}

Abychom se mohli soustředit na zvolenou problematiku, bylo potřeba záznamy výuky rozčlenit na lépe uchopitelné části - výukové situace. Samotný pojem situace v odborné literatuře (at' již lingvistické či pedagogické) není užíván jako jednoznačný „terminus technicus“ (Deppermann \& Spranz-Fogasy, 2001, s. 1148). Jak uvádí Kaderka (2013, s. 36), pojem situace odkazuje k teoriím jednání a teoriím komunikace a jeho užití naznačuje holistické pojetí komunikace - jejím prostřednictvím bývá vysvětlována celá řada diskursivních praktik v různých kontextech.

V této studii uplatňujeme pojetí situací vycházející z etnometodologie. Situace je zde místem, kde se vytváří význam a zároveň je místem socializace (srov. Schütze, 1987, s. 161). Situace vzniká na základě jednání aktérů v konverzaci, což lze dokumentovat pomocí konkrétních promluv a ve specifických případech i kontextuálních rámců.

vili prvních 10 škol a požádali je o spolupráci. Osloveni byli v prvé řadě ředitelé škol a až poté samotní učitelé německého jazyka. $V$ případě odmítnutí jsme oslovovali vždy další školu v pořadí.

23 Z důvodu zachování anonymity uvádíme učitele pod kódovými označeními A-G. Ve výsledkové části pak uvádíme vždy kód učitele a pořadí natočené hodiny. Ze stejného důvodu užíváme pouze označení „učitel“ pro učitele i pro učitelky. 
Protože se v této studii pohybujeme v kontextu výuky, budeme pojednávat o tzv. výukových situacích. Výukové situace pojímáme jako součást procesu výuky, která je vymezená časem, místem, obsahem výuky a ve které se odehrává interakce mezi učitelem a žákem/žáky a interakce žáka s obsahem výuky (srov. Janík et al., 2013, s. 184). Je zřejmé, že nelze určit přesné hranice, kdy (výuková) situace ${ }^{24}$ začíná a kdy končí (srov. Kaderka, 2013). Výuková situace se vyznačuje vysokou mírou komplexnosti, je hodnotově determinovaná a podílí se na kvalitě výuky v závislosti na své pozici ve struktuře výuky a na podílu přispění k dosažení cílů výuky (srov. Janík et al. 2013, s. 377). Z toho vyplývá, že je třeba ji vnímat v souvislosti s výukovými cíli a zohledňovat situační souvislosti dané výuky (srov. Janík et al., 2013, s. 232).

Z hlediska struktury chápeme výukovou situaci jako tematicky, prostorově a časově uzavřenou interakční výměnu (exchange) mezi učitelem a žáky (popř. mezi žáky) ovlivněnou obsahem výuky. Situace je zde celek, ve kterém se mohou odehrávat jednotlivé výměny či sekvence výměn, popř. i více sekvencí.

\subsection{Metoda analýzy}

Výzkumná metoda - konverzační analýza ${ }^{25}$ - představuje možnost zkoumat volbu použití jazyka v promluvě, a to relativně nezávisle na vnějších sociálních faktorech. Dalším rysem konverzační analýzy je snaha charakterizovat konverzaci na základě jí samé, na základě vlastní formy komunikačního jednání - nabízí tzv. emickou perspektivu sociální reality. To znamená, že poskytuje náhled na konverzaci (a vznik znalostí) výlučně z interní perspektivy vlastní konverzace (ten Have, 2007, s. 34).

24 Totéž platí i pro sekvence (viz dále).

25 Kořeny konverzační analýzy lze spatřovat $\mathrm{v}$ etnometodologických výzkumných př́istupech ke zkoumání komunikace. Konverzační analýza vznikla ve Spojených státech amerických v 60. letech minulého století, na jejím vzniku se významnou měrou podíleli sociologové Erving Goffman (perspektivou každodenního jednání), Harold Garfinkel (rozvojem etnometodologického přístupu) a za zakladatele jsou považováni Harvey Sacks, Emanuel Schegloff a Gail Jeffersonová. Zájmem těchto sociologů bylo teoretizování všednosti a každodenního jednání. Na základě nahrávek autentických rozhovorů zkoumali zmínění autoři interakce v konverzacích a došli $\mathrm{k}$ tomu, že interakce není náhodná, ale organizovaná, a že produkce promluvy jsou svým způsobem metodické (tj. lze v nich nalézt jistá pravidla). Konverzační analýza jako výzkumná metoda se od té doby etablovala jako uznávaná metoda kvalitativně orientovaného výzkumu komunikace (ve smyslu talk), současné př́stupy shrnuje např. Heritage (2016). 
V rámci konverzační analýzy se předpokládá, že aby mohli aktéři interakce na jedné straně realizovat svoji promluvu srozumitelně a na druhé straně promluvu interpretovat, je zapotřebí určitého "mechanismu“ - tzv. sekvenční organizace. Právě tyto „mechanismy“ umožňují výzkumníkům analyzovat postup interakce. Středem zájmu konverzačních analytiků tak není ani „reálný význam“ ani „kognitivní stav“ (Seedhouse, 2004, s. 21), ale spíše to, jak aktéři v interakci realizují sérii souvisejících sociálních jednání pomocí jazyka jako prostř̌edku (média), a zároveň jak se rozvíjí intersubjektivní poznání. ${ }^{26}$ Základní oblastí zájmu konverzační analýzy jsou tzv. párové sekvence (adjacency pairs). $\mathrm{V}$ rámci sekvencí se konverzační analýza zaměřuje na stř́dání replik (turn-taking). Z pohledu struktury sekvencí pak na preferenční organizace (preference organisation) a opravy (repairs) (viz např. Mazeland, 2006).

V rámci konverzační analýzy jako metody lze rozlišovat dva základní přístupy: (1) konverzační analýzu zaměřenou na každodenní konverzaci, tzv. čistou konverzační analýzu, jak ji navrhli (především) Sacks, Schegloff a Jeffersonová, a (2) konverzační analýzu v institucionálním kontextu (napřv v pojetí Heritage, 2005). V rámci konverzace $v$ institucionálním kontextu zastávají aktéři specifické role a jsou jim v konverzaci připisovány odpovídající identity (např. učitel a žák, lékař a pacient), mají různou míru akceptovaných nástrojů k tomu, jak „přimět“ komunikačního partnera k jednání. V neposlední řadě poskytuje institucionální kontext specifický rámec, na který jsou navázané typické jazykové „procedury“ (např. Drew \& Heritage, 1992). Protože se v naší práci zaměřujeme na kontext výuky (naší jednotkou analýzy je výuková situace), využíváme právě institucionální konverzační analýzy. ${ }^{27}$

\section{Konverzační analýza ve výzkumu výuky cizích jazyků}

Na výuku lze v kontextu konverzační analýzy nahlížet na třech úrovních: (1) na mikroúrovni se dají sledovat interakce v konkrétní výukové situaci, (2) na úrovni výuky cizího jazyka se lze zaměřit na interakci jako na př́íklad komunikace v dané vyučovací hodině a (3) na institucionální úrovni je interakce chápána jako příklad komunikace ve třídě, kde je vyučován cizí jazyk

26 Považujeme za potřebné zmínit, že v rámci konverzační analýzy nestojí v centru pozornosti jazyková forma, ale spíše způsob, jak jsou obvykle vyjadřovány rozdíly v sociálním jednání. Základní otázku tedy představuje spíše to, proč bylo vyřčeno „tohle“ „takto“ a právě v tento moment (Seedhouse, 2004, s. 18).

27 Podrobnější popis metody konverzační analýzy v pedagogicky orientovaném výzkumu nabízí v českém jazyce například Tůma (2016), v kontextu osvojování cizího jazyka v anglickém jazyce např. Seedhouse (2004), Markee a Kasper (2004) či McKay (2006). 
(srov. Seedhouse, 2004, s. 208-213). V této studii se zaměříme na konverzační analýzu na institucionální úrovni - tj. budeme analyzovat situace, které jsou „typické“ pro výuku cizího jazyka obecně. ${ }^{28}$

Pro výzkum výuky cizího jazyka je podstatné, že pomocí konverzační analýzy lze nahlížet některé struktury interakce při učení se cizímu jazyku a jeho osvojování (Markee \& Kasper, 2004, s. 496). V této studii považujeme též za dủležité, že přes zaměření na učitele nebudeme opomíjet skutečnost, že i žáci představují aktivní aktéry výuky, kteří transformují úlohu (jež je zadána učitelem) do jednání v dané situaci (srov. Coughlan \& Duff, 1994).

\section{Konverzační analýza ve výzkumu mnohojazyčnosti}

Výzkum v oblasti mnohojazyčnosti založený na konverzační analýze se nejčastěji zabývá bilingvní konverzací. ${ }^{29}$ Pole výzkumů bilingvní konverzace je sice poměrně široké, lze však najít určité průsečíky, jež celou paletu výzkumů spojují, jako např. že na stř́́dání kódů (code-switching; např. Auer, 2013; Gafaranga, 2007; Heller, 1988) je nahlíženo jako na přirozené jazykové jednání (ve smyslu practice). V tomto kontextu se spíše než o určení toho, zda se jedná o chybu, či nikoliv, výzkumníci zaměřují na to, proč a jak bilingvní jedinci jazyky přepínají, ${ }^{30}$ resp. jak je užívají (srov. Cashman, 2010, s. 275). Gumperz (1982, s. 27) pak poukazuje na to, že užívání jazyků není vždy stejné, je svázáno s celou řadou sociálních faktorů a že použití dvou jazyků v konverzaci je spojeno s informací o hodnotách a postojích.

\subsection{Vlastní metodologický postup}

Náš výzkum byl realizován ve třech fázích: (1) fáze přípravy a sběru dat, (2) fáze zpracování dat a (3) fáze analýzy dat. V rámci př́pravy a sběru dat jsme pořizovali videonahrávky výuky německého jazyka (a také terénní zápisky či kontextuální data).

28 Je třeba zdůraznit, že tato studie má kvalitativní charakter, není možné tedy zobecňovat na veškerou výuku německého jazyka.

29 Často je však pojmem „bilingvní“ míněna mnohojazyčná konverzace. Vztahem pojmu bilingvismus a mnohojazyčnost jsme se zabývali jinde (viz Janík, 2013).

30 Jako př́íklad lze uvést jeden z prvních výzkumů bilingvní konverzace, který realizovali Blom a Gumperz (1972) ve dvojjazyčné oblasti Norska. Na základě etnografického výzkumu se zabývali tím, jaké jazyky jsou v jakých situacích využívány. Autoři např́íklad poukázali na to, že zkoumaní jedinci přepínali jazyky v různých situacích (v konverzacích s turisty, v komunikaci s úřady, ve třídě). 
Zpracování dat pak spočívalo v transkripci videozáznamů dle transkripčního systému užitého v rámci projektu IVŠV Videostudie (Najvar et al., 2011) v programu Videograph (Rimmele, 2002). Tento transkript byl spolu s vlastní videonahrávkou využit pro identifikaci našich situací. Začátek situace byl lokalizován podle první repliky té sekvence, ve které bylo na (libovolném místě v sekvenci) identifikováno užití anglického jazyka učitelem. Konec situace byl lokalizován tam, kde již aktéři dále nereagují na předchozí repliku či téma. Poté, co jsme situace identifikovali, byla provedena jejich druhá transkripce na základě transkripčního systému GAT2 ${ }^{31}$ (Selting et al., 2009). V další fázi jsme přistoupili k vlastní konverzační analýze v identifikovaných situacích. Využili jsme tzv. institucionální konverzační analýzy - tzn. zohledňovali jsme specifický kontext výuky cizích jazyků.

Poté, co jsme popsali vlastní metodologický postup, zaměřme se na výsledky této studie. $V$ rámci výsledkové kapitoly naznačíme obecnou charakteristiku identifikovaných situací a pak nabídneme detailnější pohled na užívání anglického jazyka ve výuce němčiny z hlediska jeho funkce. Při interpretaci výsledků se budeme zabývat nejen vlastní organizací situací, ale budeme vyzdvihovat i jejich oborovědidaktické perspektivy.

\section{$4 \quad$ Výsledky studie}

V následující kapitole představíme výsledky naší studie. Celkově jsme identifikovali 24 situací, ve kterých učitel užívá anglický jazyk, a ty jsme se pokusili „typologizovat“. Před tím, než se budeme věnovat jednotlivým „typickým“ situacím, naznačíme obecnou charakteristiku jejich organizace.

V analyzovaných situacích převažuje frontální výuka (mechanismem střrídání replik ve frontální výuce se zabýval např. McHoul, 1978), která je typická tím, že učitel řídí interakci ve třídě, může kdykoliv promluvit a může vybírat následujícího mluvčího či mu slovo odebrat. Naproti tomu žák smí svojí repliku započít jen tehdy, když je v učitelově replice osloven - tedy pokud je vyvolán. ${ }^{32}$

31 Tento transkripční systém lépe zachycuje veškerou verbální komunikaci, a je proto pro konverzační analýzu vhodnější.

32 Ačkoli je frontální styl výuky často (a mnohdy oprávněně) kritizován (např. Gudjons, 2000), zejména v souvislosti $s$ výukou cizích jazyků, lze u něj nalézt i některá pozitiva. Stř́dání replik ve frontální výuce umožňuje efektivně řídit interakce ve třídě a důsledkem může být to, že se ke slovu dostane větší počet žáků. Navíc vždy mluví pouze jeden žák a nedochází tak k překryvům a neporozumění. Učitel má také lepší možnost kontrolovat, zda žák porozuměl 
Právě pro frontální výuku je charakteristická IRF struktura (např. Mehan, $1979^{33}$ ), která byla identifikována i ve většině námi analyzovaných situací. IRF struktura je obecně považována za typickou sekvenci interakcí ve výukovém kontextu (Seedhouse, 2004) a je charakterizována třemi fázemi: iniciace (initiation), odpověd' (response) a zpětná vazba (feedback). Fáze iniciace bývá realizována otázkou učitele či zadáním, popř. vysvětlením úlohy. Fáze odpovědi bývá provedena žákem a vztahuje se právě k iniciaci. Ve fázi zpětné vazby je učitelem reflektována odpověd' žáka a může obsahovat její přijetí, nepřijetí a také rozšiřující komentář. $V$ našich situacích nebyla patrná pouze „čistá“ IRF struktura, ale často došlo i na její modifikace - a to zejména tehdy, když byl u žáka patrný jazykový problém či vyjádřený nedostatek znalostí. V tom případě byla IRF struktura rozšířena o vloženou (opravnou) sekvenci či nápovědu. Dále byla zřejmá vzájemná svázanost jednotlivých sekvencí v situacích.

Z analýzy vyplynulo, že anglický jazyk užívají učitelé v rámci komentářo a nápověd. Jako komentár chápeme ve shodě s Kalthoffem (2000) takový typ promluvy, jehož pomocí je vnášen nový obsah do výuky. Zmíněný autor poukazuje na to, že komentáře jsou situačně podmíněné - jejich podoba je závislá na předchozí replice, nebo/a mohou další sekvenci replik zahájit. Z hlediska funkce jsou komentáře takové promluvy, které mají vysvětlující charakter a rozvíjí zpětnou vazbu (či evaluaci) nebo slouží jako výklad.

Dále užívají učitelé anglický jazyk jako nápovědu (cluing ${ }^{34}$, např. McHoul, 1990). Jejím cílem je napomoci žákovi při řešení problému v interakci, který nastane (např. v důsledku nedostatečné jazykové kompetence nebo v důsledku nepozornosti aj.). Z hlediska sekvenčního řazení je nápověda učitele iniciací žákovy sebeopravy (viz např. Auer, 2014, s. 136), a to v rámci vložené opravné sekvence (viz dále).

Je třeba zdůraznit, že se v naší analýze zaměříme na organizaci celých situací (nikoliv na samotné komentáře či nápovědy). Dále považujeme za důležité upozornit, že se v této kapitole nebudeme zabývat všemi identifikovanými situacemi, ale pouze vybranými situacemi, které zastupují určitý trend.

tomu, o čem je ve výuce řeč. Typický třetí tah může přispět k upevnění a rozšíření znalostí žáka. $V$ neposlední řadě $v$ rámci řízené interakce učitelé snadněji naplňují didaktické cíle (Meyer \& Meyer, 1997, s. 37).

33 Mehan ve své práci uvádí IRE (initiation-response-evaluation).

34 McHoul používá cluing, jenž je akceptovaným standardem v australské angličtině. 


\subsection{Situace, ve kterých učitel užívá anglický jazyk v komentář́ích}

$\mathrm{V}$ této kapitole představíme situace, ve kterých učitel užívá anglický jazyk v komentárích. $\mathrm{V}$ našem výzkumném vzorku byl anglický jazyk v komentářích nejčastěji patrný ve formě rozšíření zpětné vazby na žákovu odpověd'. Jako prŕklad lze uvést situaci 1 . Kontext této situace se týká opakování ročních období. Zadání úlohy zní tak, že učitel německy vyjmenovává měsíce $\mathrm{v}$ roce a žáci mají psát odpovídající roční období. V naší situaci však došlo k odchýlení od zadání, a je řešen význam slova „Sommer“ (léto) a k psaní odpovědí v této situaci nedošlo.

Situace 1 (učitel G4)
01 U: Já řeknu, podívej se, já řeknu Mai a ty napíšeš Frühling, jo? ( - ) Takže Sommer.
02 Z1: Léto.
03 U: Podívejte se na tu podobnost s tou angličtinou. <<angl. výslovnost $>$ SUmmer $>=$ $<<$ něm. výslovnost $>$ SOmmer ${ }^{34}$.
04 Z2: A dostanu jedničku, když to budu mít správně?
$05 \mathrm{U}: \quad$ No když to budeš mít správně, dostaneš jedničku.
06 U: ( - ) Frühling (.) Herbst

V naší situaci učitel nejdříve vysvětluje úkol, avšak poté se ptá žáků na význam slova „Sommer“ v češtině (řádek 01). Žák odpovídá nahlas a jeho odpověd' je učitelem přijata, i když neposkytuje explicitní zpětnou vazbu učitel ve své replice (řádek 03) reaguje na žákovu odpověd' tak, že přichází s komentářem, který plní funkci rozšířené zpětné vazby. Učitel užitím anglického jazyka v komentáři, kterým uzavírá sekvenci týkající se léta, poukazuje na podobnosti německého jazyka s anglickým. Další repliky (řádek 04 a 05) lze interpretovat jako sekvenci vztahující se k náročnosti řešení úkolu a tuto sekvenci iniciuje žák tím, že se dožaduje dobré známky (pokud splní úlohu správně). Zároveň tím dává žák najevo, že by mohl získat dobrou známku tedy vyjadřuje sebedůvěru ve svoji znalost. Tato žákova replika (řádek 04) následuje bezprostředně po vysvětlujícím komentáři na řádku 3. Je tudíž možné spatřovat souvislost $s$ komentářem učitele, ve kterém poukázal na podobnost anglického a německého jazyka, a snahou žáka o získání dobré známky v důsledku (na řádku 04 vyjádřené) sebedůvěry. Učitel v následující

35 Naznačení jazykových signálů (viz transkripční systém $\mathrm{v}$ př́loze 1) užíváme $\mathrm{v}$ těch př́padech, kdy je třeba zdůraznit či odlišit anglický a německý jazyk. Pokud je promluva realizována německy, česky či anglicky a není třeba to zdůraznit, je ponechána ve svém jazyce bez signalizace. 
replice potvrdí žákovi, že může získat „,jedničku“ a dále (od řádku 06) se vrací k původní úloze - tj. roční období a měsíce v roce.

Zaměřme se nyní na další situaci, v níž je anglický jazyk patrný v komentáři učitele. Situace 2 je zarámována aktivitou, ve které se učitel ptá žáků na části oblečení a jako pomoc při odpovědi mají žáci k dispozici obrázky v učebnici.

Situace 2 (učitel D1)

01 U: Ano, plavky. A plavky v celku, jo? Plavky v celku dámské. Hm [ano]. Další, Vlád’o?

02 Z: $\quad$ Das << angl. výslovnost $>$ sweatshirt >

03 U: Ano, ja. Das kennt ihr, ist von englisch, von englisch, ja? Hm (ano). Báro?

Situace začíná tím, že učitel vyzve žáka k odpovědi, v níž má uvést část oblečení a jako opora mu slouží obrázky v učebnici. Žák ve své odpovědi použije slovo „sweatshirt", které se používá i v německém jazyce - resp. jedná se o anglický výraz, jenž je do současného německého jazyka integrován. V následující replice učitel přijme odpověd' žáka (řádek 03), v komentáři upozorňuje na to, že dané slovo by měli žáci znát z anglického jazyka, a zakončí jej responzivní otázkou a přitakáním.

Zatímco v první situaci anglický jazyk „vnesl“ do výuky sám učitel, v této situaci je komentář reakcí na žákovu promluvu, v níž je užit anglický jazyk. Je zajímavé, že na rozdíl od většiny analyzovaných situací učitel komentář pronese v německém jazyce. Dále se učitel ( $a$ ani žák) již k angličtině nevyjadřuje a přechází $\mathrm{k}$ další otázce.

Komentář učitele, v němž byl užit anglický jazyk, jsme v našem vzorku identifikovali i v iniciační fázi IRF struktury. Jako př́íklad lze uvést situaci 3, jejíž kontext je následující: učitel chtěl s žáky opakovat slovíčka, která se žáci učili $\mathrm{v}$ minulých hodinách. Tématem byly měsíce $\mathrm{v}$ roce. Zvláštní pozornost je věnována žákům, kteří v minulé hodině chyběli.

\section{Situace 3 (učitel G3)}

01 U: Tak, Martine ( ) Tak a já dám nějaká jednoduchá slovíčka pro ty, co tady nebyli (.) Kdo tady nebyl minulou hodinu?

02 Z1: Já.

03 U: Je to velice snadné. ( ) Je to velice podobné jak angličtině, akorát že ( . ) Takže Januar. Jak to máte $v$ angličtině?

04 Z1: < < angl. výslovnost> January>. 
05 U: << angl. výslovnost> January >, jo? Takže v němčině říkáme << něm. výslovnost> Januar > jako j. Únor to je Februar. Březen tady máte na tabuli. März.

06 Z1: März.

07 U: Jo? (.) Duben?

08 Z2: Duben je << něm. výslovnost $>$ April $>$.

09 U: April, jo? Všichni řeknou April.

Učitel na začátku naší situace uvádí aktivitu, která bude probíhat (pozn.: již na jiném místě hodiny učitel uvedl, že se budou zabývat měsíci v roce), a vybírá žáka, jenž chyběl. Žák 1 se přihlásí, v následující replice učitel pokračuje v iniciaci aktivity a podává vysvětlující komentář (řádek 03). Tento komentář má podobu výkladu a odkazuje v něm na to, že výrazy pro měsíce jsou $\mathrm{v}$ německém a anglickém jazyce velmi podobné. $\mathrm{V}$ první části komentáře učitel motivuje žáky, když říká, že „je to velice snadné“, v další části promluvy upozorňuje na podobnosti. Poté si vybírá konkrétní případ - měsíc leden (Januar) - a ptá se žáka na anglický výraz. Žák přijímá otázku a odpovídá anglicky (řádek 04). V následující replice učitel poskytuje pozitivní zpětnou vazbu zopakováním „January“ a připojuje komentář - na konkrétním příkladu (January/Januar) ukazuje na jedné straně podobnost mezi jazyky, na druhé vyzdvihuje také rozdílnou výslovnost. Svým komentářem učitel tuto sekvenci uzavírá a věnuje se dalším měsícům (řádek 05).

Na rozdíl od první analyzované situace byl komentář identifikován na začátku situace a měl výkladovou funkci a učitel jako výkladový rámec užil právě angličtinu. Sled následných replik lze pak chápat jako elaboraci toho, co se vysvětlovalo $\mathrm{v}$ prvním komentáři (avšak vliv anglického jazyka již dále nebyl identifikován, a proto jsme pokračování situace nezahrnuli do analýzy). Ve druhém komentáři ( $\mathrm{v}$ pozici třetího tahu) se pak učitel vrátil k angličtině a celou sekvenci uzavřel.

Pokud bychom chtěli shrnout tuto část našich výsledků, dalo by se říci, že komentáře, ve kterých je patrný vliv anglického jazyka, mají - jak jsme již uvedli výše - funkci rozšíření zpětné vazby a výkladu (viz např. Kalthoff, 2000; Mori, 2002). Z hlediska organizace komentáře v naprosté většině námi analyzovaných situací uzavírají sekvence (viz Kalthoff, 2000) - jsou reakcí bud' na odpověd' žáka, nebo na opravnou sekvenci, a proto lze na ně nahlížet jako na rozšíření zpětné vazby ve struktuře IRF. Je zde patrná organizace promluv, která je typická pro výuku - totiž že po párové sekvenci následuje 
uzavírající třetí replika (sequence-closing third), kterou realizuje první mluvčí. Ten tak může vyjádřit přijetí informace, dát najevo svůj postoj nebo hodnotit (Schegloff, 2007, s. 118-142). Většinou tedy komentáře reagují na předchozí repliky žáků (viz situace 1 a 2), v nichž však anglický jazyk může, ale i nemusí být patrný. Komentáře $s$ užitím anglického jazyka se $\mathrm{v}$ malé míře vyskytují i v iniciační fázi (viz situace 3).

$\mathrm{Z}$ oborovědidaktického hlediska slouží učitelovy komentáře $\mathrm{k}$ reflexi a prohloubení žákovských znalostí a přinášejí zobecnění (srov. Kalthoff, 2000). Anglický jazyk je užíván učiteli jako legitimní vysvětlující rámec, v němž odkazují na znalost anglického jazyka jako prvního cizího jazyka, jejž se žák učí ve škole.

\subsection{Situace, ve kterých učitel užívá anglický jazyk v rámci nápovědy}

Dále představíme situace, v nichž je užit anglický jazyk jako nápověda. První analyzovaná situace (situace 4) v této podkapitole je zarámována prací $\mathrm{s}$ učebnicí. $\mathrm{V}$ té žáci řeší úlohu, $\mathrm{v}$ níž vystupují rodiny, které mají příjmení ročního období. Na základě obrázků a popisků v učebnici mají žáci říci, kde tyto rodiny bydlí. Učitel je upozorní právě na to, že př́ijmení rodin mají v této úloze zároveň význam ročních období, a v rámci řešení úlohy se chystá zjistit, zda žák zná význam slova „Frühling“.

\section{Situace 4 (učitel G4)}

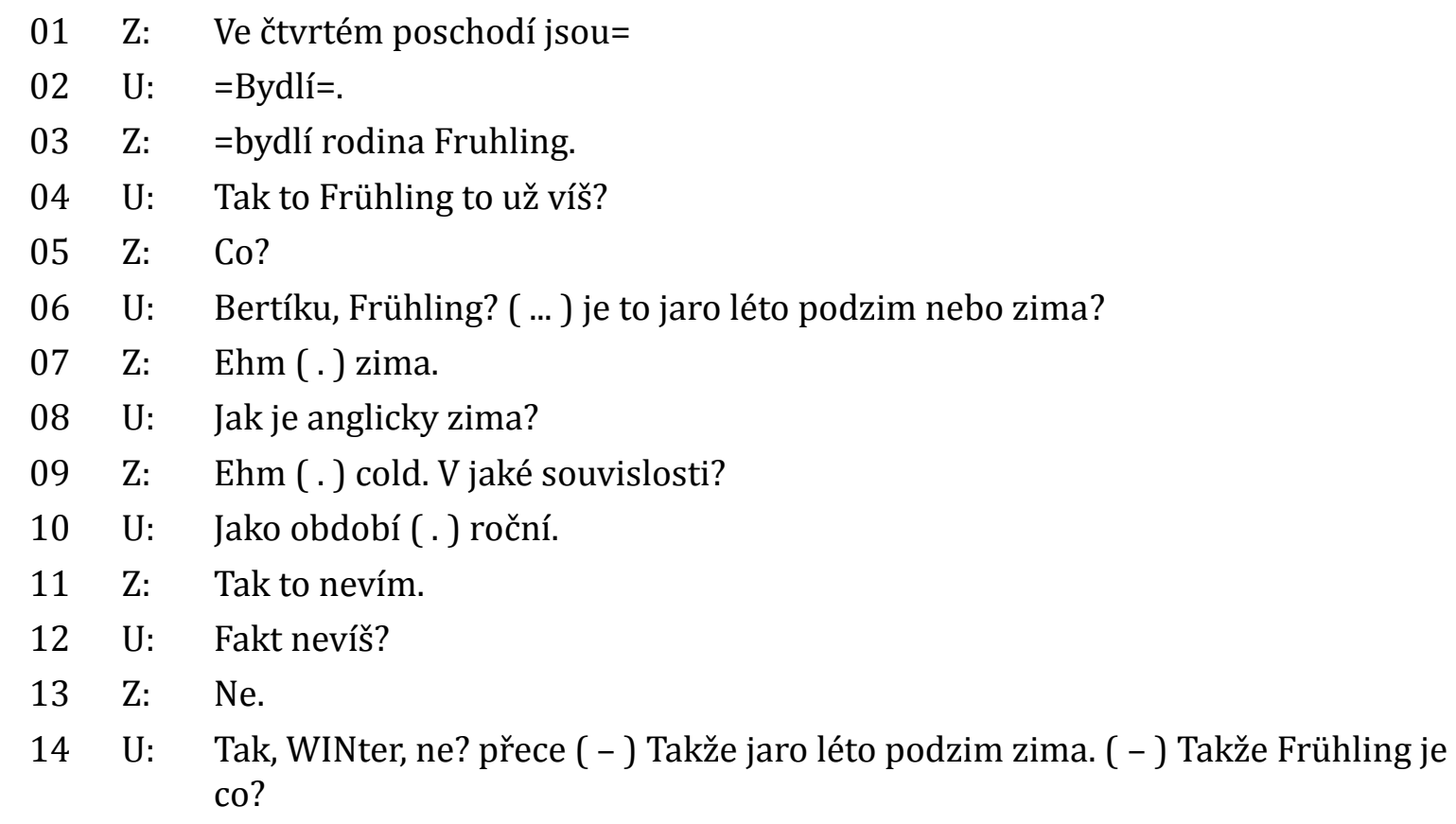




$\begin{array}{lll}15 & \text { Z: } & \text { Podzim. } \\ 16 & \text { U: } & \text { März April Mai } \\ 17 & \text { Z: } & \text { [J a r o]. } \\ 18 & \text { U: } & \text { [Das, was] haben wir jetzt. Co máme nyní. Jaro, jo? } \\ 19 & \text { Z: } & \text { Jaro. }\end{array}$

V naší situaci vybízí učitel žáka, aby řekl, co znamená „Frühling“ (řádek 04), žák ale odpovídá otázkou, kterou dává najevo, že není schopen odpovědět (řádek 05). Učitel zopakuje otázku a poté jako nápovědu zkouší říci roční období. Žák odpovídá „zima“ a dle hezitačního „ehm“ lze usuzovat, že žák odpověd’ neví (řádek 07). Následující otázkou (řádek 8) učitel začíná vloženou opravnou sekvenci, která se týká zimy, a jejím prostřednictvím se učitel snaží elicitovat anglický jazyk. Žák odpovídá „cold“ (řádek 09), což je do jisté míry správný překlad a žák se tedy svým způsobem orientuje na otázku učitele. Může se tedy jednat o tzv. preferovanou odpověd' doplněnou o protiotázku, ve které žák požaduje upřesnění otázky („v jaké souvislosti?“). My se však přikláníme spíše k interpretaci, že se jedná o tzv. nepreferovanou odpověd' (viz např. Boyle, 2000), nebot' je uvedena příznakovým (marked) hezitačním „ehm“, následuje pauza a odpověd” „cold“ je doplněna otázkou, jejímž prostřednictvím se žák snaží vyhnout odpovědi. Že jde o žákovu snahu vyhnout se odpovědi a snahu přerámcovat průběh konverzace usuzujeme z předešlého průběhu celé situace: již z učitelova výroku na řádku 6 , kdy vyjmenovává roční období, je „souvislost“ ročních období zřejmá a dále tuto interpretaci podepírá kontext situace - totiž práce s učebnicí, kde jsou roční období uvedená jako příjmení rodin (viz výše). ${ }^{36}$ Učitel přesto žákovi v další replice napovídá kontext ročních období, čímž se vrací ke své otázce a nadále požaduje odpověd'. V následující replice žák uvádí, že neví, jak se řekne „zima“ $\mathrm{v}$ kontextu ročních období (což lze opět interpretovat jako nepreferovanou odpověd', v tomto př́padě tzv. non-answer - responce; viz Stivers \& Robinson, 2006). Učitel reaguje otázkou, v níž se snaží ujistit, že žák odpověd’ opravdu nezná (request for confirmation; Sert \& Walsh, 2013). Žák odpoví, že neví, a následuje zpětná vazba učitele, v níž uvede správnou odpověd' (o průběhu interakcí v prrípadě, kdy student vyjádří svůj nedostatek v cizím jazyce blíže např. Sert \& Walsh, 2013). Touto replikou je uzavřena vložená sekvence o „zimě“ a učitel se vrací zpět k tématu „jaro“.

36 Na snahu vyhnout se odpovědi či záměrně dávat nepreferovanou odpověd' usuzujeme i z průběhu předešlé komunikace (která zde není z prostorových důvodů uvedena), v níž se žák různými způsoby snaží vyhýbat odpovědím. 
Anglický jazyk je v této situaci učitelem užit jako nápověda a byl užit v důsledku žákovy nedostatečné znalosti německého jazyka. Tato nápověda ale nevedla k takové odpovědi, kterou učitel požadoval - na konci sekvence týkající se zimy, v níž je užit anglický jazyk, musel učitel sám říct správnou odpověd'. Pro zodpovězení otázky na význam pojmu „Frühling“ pak využil jiného druhu nápovědy (vyjmenoval jarní měsíce, řádek 16) a tato nápověda byla již úspěšná. $Z$ toho je patrné, že užití anglického jazyka v nápovědě nemusí vždy vést ke správné odpovědi a jiné formy nápovědy se mohou projevit jako účinnější.

Přejděme nyní $\mathrm{k}$ analýze další situace, v níž anglický jazyk vstupuje do výuky v rámci nápovědy. Na př́kladu následující situace (situace 5) ukážeme podobu interakcí ve výuce, ve kterých je anglický jazyk užit v nápovědě a v komentáři, jenž nápovědu rozšiřuje. Analyzovaná situace se odehrála v rámci úlohy, v níž mají žáci opakovat zvířata. Při opakování slova „nosorožec“ (Nashorn) učitel v té souvislosti změní téma a ptá se žáků na slovo „nos“ (die Nase) a následně na další části obličeje.

Situace 5 (učitel G1)

01 U: ( ) Takže die Nase je nos. Tak, co ještě známe, co souvisí s hlavou?

02 Z1: Uši.

03 U: Uši, jak se řeknou uši? ( - - - ) Takže vlasy možná.

04 Z2: Haare.

05 U: Die Haare, hm. (ano) Deine Haare sind blond nebo gelb, jo? Wie sehen ihre Haare aus. Jak vypadají její vlasy? ( . ) Patriku, jak vypadají Terčiny vlasy? Můžeš říct třeba: sie sind gelb, grün, blau.

06 Z3: Grün.

07 U: Grün? Findest du, dass sie grün sind? ( - ) Filipe otázka na tebe, jak vypadají její vlasy?

08 Z4: Prosím?

09 U: $\rightarrow$ Zkus, jak vypadají její vlasy? Zkus říct Ihre Haare sind ((učitel píše na tabuli)) ( - ) a doplníme to přídavné jméno barvu.

10 Z5: Čí? Terčiny?

11 U: Terčiny, hm.

12 Z5: Šedý.

13 ZZ: ((smích))

14 Z6: Jak řeknu červený?

15 U: Červený?

16 Z6: Ne. (.) Jak je hnědá? 
17 Z7: Bílý.

18 U: No, to je jak anglicky.

19 Z6: << něm. výslovnost>Braun>.

20 Z?: << něm. výslovnost>Braun>.

21 U: Braun. Pomožte si tou angličtinou, když už je spousta věcí je podobná, jo? Tak, rád bych se vrátil $k$ těm zvířatům. Já jsem jenom trošku odbočil k vlasům.

Naše situace začíná tak, že se učitel žáků ptá na barvu vlasů (řádek 9). Žák je učitelem vybízen $\mathrm{k}$ tomu, aby řekl, jakou barvu vlasů má jedna spolužačka. Pro nás je však zajímavá sekvence až od momentu, kdy se šestý žák ptá učitele na červenou (řádek 14). Učitel reaguje protiotázkou, ve které zopakuje žákovu otázku. Tato protiotázka má charakter podnětu k sebeopravě ${ }^{37}$ - dotčená spolužačka totiž nemá červené vlasy, což je patrné z videozáznamu. Žák přijme iniciaci k sebeopravě, avšak neodpoví př́mo, ale ptá se na hnědou barvu (řádek 16), resp. na německý výraz pro hnědou. Učitel tentokrát reaguje nápovědou, ve které elicituje užití anglického jazyka (řádek 18). Žák na nápovědu reaguje německým výrokem (spolu s dalším žákem) „braun“, což je slovo (zejména z fonetického hlediska) velmi podobné anglickému brown. Z hlediska struktury je patrné, že odpověd' $\mathrm{v}$ německém jazyce namísto ( $\mathrm{v}$ nápovědě požadované) angličtiny neměla vliv na průběh konverzace. Po společné odpovědi dvou žáků následuje její potvrzení (tím, že učitel odpověd' zopakuje) a dále komentář, $v$ němž učitel navazuje na nápovědu a zobecňuje možnosti využití znalosti angličtiny. Tato sekvence pak není dále rozvíjena, učitel svým komentářem uzavřel problém barvy vlasů a přechází zpět k tématu zvířat.

V této situaci je patrné - pro výuku typické - užití protiotázek učitele (viz napřr. Markee, 2000) a opakování žákovské otázky (viz napřr. Long et al., 1998), které mají iniciovat sebeopravu (řádek 15). Pro nás je však zajímavá zejména nápověda na řádku 18, v níž se učitel snaží elicitovat žákovu znalost němčiny využitím znalosti anglického jazyka - tzv. metalingvistické vodítko (metalinguistic clue; Lyster, 1998). Na rozdíl od předchozí situace mohlo učitelovo užití anglického jazyka přispět ke „správné“ odpovědi žáka. Dále je zde patrné, jak si učitel touto protiotázkou vytvořil prostor pro komentář (řádek 21), ve kterém se vrací k možnosti využití anglického jazyka

37 Zopakování odpovědi $\mathrm{s}$ chybou patři $\mathrm{k}$ poměrně častým způsobům iniciace opravy (např. Lyster, 1998). 
a informaci z nápovědy rozšiřuje. Komentář pak učitel zakončil responzivní otázkou „jo?“, čímž ukončil tuto sekvenci a zároveň i naši situaci.

Pokud bychom chtěli shrnout tuto podkapitolu, lze říci, že anglický jazyk v nápovědě užívají učitelé v našem vzorku většinou jako reakci na chybu či vyjádření nedostatku znalostí (claiming insufficient knowledge, např. Sert \& Walsh, 2013), jež vyžaduje opravu, v některých situacích figuruje ale i jako reakce na nepreferovanou odpověd', kterou se pokouší učitel vrátit pozornost k řešení úlohy. Nápovědy mají nejčastěji podobu protiotázek, jejichž užitím učitel iniciuje žákovu sebeopravu (viz např. Markee, 2000). Nápovědy obsahují tzv. metalingvistická vodítka - to znamená, že je v nich patrná informace či otázka vztažená $\mathrm{k}$ jazykům. $\mathrm{Z}$ oborovědidaktického hlediska lze konstatovat, že iniciace $\mathrm{k}$ sebeopravě a nápovědy jsou považovány za jeden $\mathrm{z}$ efektivních způsobů zacházení s chybou či jazykovým deficitem (srov. MacKey \& Philip, 1998). Nabízí totiž žákovi možnost reflexe vlastní chyby či jazykového nedostatku čímž by měly přispět k lepšímu efektu při učení se cizímu jazyku.

\section{Závěr a diskuse}

V této studii jsme představili analýzu situací, v nichž učitel užívá anglický jazyk ve výuce německého jazyka. Výsledky naznačují „přirozeně“ dynamickou povahu učitelského zacházení s jazyky.

$\mathrm{V}$ případě, že je anglický jazyk užit učitelem, děje se tak v rámci nápověd a komentářů. Z námi analyzovaných situací vyplývá, že komentáře či nápovědy obvykle nevstupují do situací v prvním tahu (iniciace) učitele (ačkoli i takové situace jsme identifikovali, viz situace 3). Jsou tedy spíše reakcí na žákovskou promluvu. $V$ případě, že žák odpoví „správně“, následuje zpětná vazba a komentář, ve kterém je užit učitelem anglický jazyk zejména k tomu, aby zdůraznil podobnosti či odlišnosti mezi anglickým a německým jazykem. V případě, že žák neodpoví podle představy učitele - udělá „,chybu“ či naznačí neznalost nastávají (v našem vzorku) dvě možnosti: Zaprvé učitel realizuje opravu žáka (čímž mu zároveň dává zpětnou vazbu) a poté následuje rozšiřující komentář s užitím anglického jazyka. Užití anglického jazyka učitelem $\mathrm{v}$ komentáři však nemusí souviset $\mathrm{s}$ užitím angličtiny žákem $\mathrm{v}$ předchozí promluvě. Zadruhé učitel iniciuje žákovu sebeopravu tím, že se mu snaží dát nápovědu. Učitelé užívali anglický jazyk v nápovědě, aby žáka „navedli“ ke „správné“ odpovědi v německém jazyce. 
Z výsledků analýz se lze domnívat, že užití anglického jazyka má žákům umožnit reflexi jazyků a je chápán jako „nástroj“ pro efektivnější učení se německému jazyku (srov. Meißner, 2004, s. 6). Ve většině situací ale nebyla patrná koncepční a promyšlená podpora mnohojazyčnosti - užití anglického jazyka mělo spíše př́ležitostný charakter a nebylo mu věnováno příliš mnoho času v rámci interakce s žáky. Na základě námi analyzovaných situací se lze domnívat, že užívání anglického jazyka je spíše spojeno s konkrétní situací a s přesvědčením učitelů a jejich postoji $\mathrm{k}$ jazykům a $\mathrm{k}$ jazykové politice ve výuce (ve smyslu „bottom-up“; viz kapitola 2.2) než s konkrétním koncepčním oborovědidaktickým přístupem ${ }^{38}$, jenž využívá jazykového repertoáru žáků a má za cíl rozvíjet mnohojazyčnost.

Z hlediska jazykové politiky směrem „bottom up“ je tímto způsobem anglický jazyk, který lze označit ve shodě s Krummem (2015) jako „elitní“, učitelem legitimizován - je užíván jako součást výuky německého jazyka. Legitimita anglického jazyka na „bottom up“ úrovni vyplývá z toho, že učitelé ví, že se všichni žáci učí anglický jazyk jako první cizí jazyk (resp. že škola nabízí angličtinu jako první cizí jazyk, což je důsledek „top-down“ jazykové politiky). Mají tudíž relativní jistotu, že se odkazují na tu část jazykového repertoáru, která je (či by měla být) žákům známa, a je tak legitimní se na ni odkazovat. Dále, vzhledem k současným sociokulturním podmínkám u nás, má anglický jazyk výsadní pozici, ${ }^{39}$ a omezovat užívání elitního anglického jazyka by mohlo být vnímáno negativně. Lze také poukázat na skutečnost, že RVP ZV již od první verze z roku 2007 doporučuje školám anglický jazyk nabízet jako první cizí jazyk, což jeho elitní pozici ještě více zdůrazňuje. Kromě zmíněného tím také tento dokument odděluje jazyky od sebe a připisuje jim různou důležitost. Vliv jazykové politiky na užívání jazyků nicméně nebyl primárním zaměřením této studie, a proto jej zde nebudeme dále tematizovat, chceme

38 V odborné literatuře se můžeme setkat s didaktickými či obecně pedagogickými koncepcemi, jako například s didaktikou terciárních jazyků (Kretzenbacher, 2009; Hufeisen \& Neuner, 2003), didaktikou intercomprehension (Bär, 2009), či s př́stupy translanguaging ve výuce (García \& Wei, 2014). Ty nabízí relativně konkrétní postupy, jak zacházet s různými jazyky a stejně tak i jejich výzkumnou reflexi často založenou na popisu jazykového jednání v interakci ve třídě.

39 Např. Neustupný \& Nekvapil (2003, s. 293) dokonce uvádějí, že v české společnosti panuje názor, že žáci, kteří se rozhodnou nestudovat anglický jazyk, sami sebe odsuzují do role méněcenných světoobčanů. Pozici anglického jazyka dokládají i doporučení ekonomických poradců z nedávné doby, která doporučovaly výuku pouze angličtiny jako jediného světového jazyka (viz např. Münich, 2011). 
zde poukázat na to, že jazyková politika na různých úrovních má souvislost s tím, jak a které jazyky budou ve výuce užívány.

Na závěr je třeba zmínit i některé limity této studie. V naší práci jsme se zabývali pouze vlivem anglického jazyka na výuku německého jazyka (tj. dvou jazyků, které se učí žáci ve škole). Bez povšimnutí jsme z výzkumných důvodů ponechali vliv „mateřských“ jazyků a dalších jazyků, které se ve výuce objevily.

Jistým omezením je i skutečnost, že konverzační analýza neoperuje s konkrétním pojetím jazyka či jazyků, ale je pro ni relevantní to, kdy a jak mluvčí „dělají“ jednotlivé jazyky jednotlivými jazyky. Nesleduje jazyk ve své lingvistické či kognitivní perspektivě, ale zabývá se jím na diskursivní úrovni. Naproti tomu oborovědidaktické teorie, teorie učení se cizím jazykům, popř. osvojování (dalších) cizích jazyků, vycházejí spíše z lingvistického (popř. kognitivního) pojetí jazyků. $V$ naší studii jsme se sice pokusili obě zmíněné perspektivy propojit - vycházeli jsme z předpokladu, že (nejen) ve výuce nelze oddělovat reálné užívání jazyků od procesů učení se cizím jazykům (popř. osvojování cizích jazyků; např. Firth \& Wagner, 1997) - ale je nám jasné, že některá místa takového propojení zůstávají rozostř̌ena. ${ }^{40}$

Závěrem dodejme, že tuto studii nevnímáme jako text, jenž by měl odhalit podoby veškerého jazykového (resp. mnohojazyčného) jednání učitelů. Naší snahou bylo spíše naznačit některé možné podoby takového jednání a poukázat na to, že učitelé jednají mnohojazyčně (a to i přesto, že kurikulární dokumenty chápou jazyky spíše jako nezávislé entity a jejich propojování nepodporují). Tím bychom rádi přispěli $\mathrm{k}$ diskusím o reálném jazykovém jednání ve výuce cizích jazyků a k rozšíření tohoto tématu nejen do oborovědidaktického, ale i do pedagogického výzkumu.

\section{Literatura}

Amir, A., \& Musk, N. (2013). Language policing: Micro-level language policy-in-process in the foreign language classroom. Classroom Discourse, 4(2), 151-167.

Auer, P. (2014). Jazyková interakce. Praha: Lidové noviny.

Auer, P. (Ed.). (2013). Code-switching in conversation: Language, interaction and identity. London: Routledge.

40 S tímto problémem se však potýkají mnohé studie zkoumající učení se cizím jazykům pomocí konverzační analýzy (viz Markee \& Kasper, 2004). 
Bär, M. (2009). Förderung von Mehrsprachigkeit und Lernkompetenz. Tübingen: Narr Francke Attempto Verlag.

Blackledge, A., \& Creese, A. (2009). Meaning-making as dialogic process: Official and carnival lives in the language classroom. Journal of Language, Identity, and Education, 8(4), 236-253.

Blom, J.-P., \& Gumperz, J. (1972). Social meaning in linguistic structure: Code-switching in Norway. In J. J. Gumperz \& D. Hymes (Eds.), Directions in sociolinguistics (s. 407-434). New York: Holt, Rinehart and Winston.

Blommaert, J. (2010). The sociolinguistics of globalization. New York: Cambridge University Press.

Bonacina-Pugh, F. (2012). Researching 'practiced language policies': Insights from conversation analysis. Language Policy, 11(3), 213-234.

Boyle, R. (2000). Whatever happened to preference organisation? Journal of Pragmatics, 32(5), 583-604.

Brown, K. (2010). Teachers as language-policy actors: Contending with the erasure of lesserused languages in schools. Anthropology \& Education Quarterly, 41(3), 298-314.

Busch, B. (2012a). Das sprachliche Repertoire oder Niemand ist einsprachig: Vorlesung zum Antritt der Berta-Karlik-Professur an der Universität Wien. Klagenfurt: Drava.

Busch, B. (2012b). The linguistic repertoire revisited. Applied Linguistics, 33(5), 503-523.

Busch, B. (2014). Building on heteroglossia and heterogeneity: The experience of a multilingual classroom. In A. Blackledge \& A. Creese (Eds.), Heteroglossia as practice and pedagogy (s. 21-40). Dordrecht: Springer.

Bybee, J. L., \& Hopper, P. J. (2001). Introduction. In J. L. Bybee \& P. J. Hopper (Eds.), Frequency and the emergence of linguistic structure (Vol. 45) (s. 1-3). Amsterdam: John Benjamins Publishing.

Canagarajah, S. (2012). Translingual practice: Global Englishes and cosmopolitan relations. Abingdon: Routledge.

Cashman, H. R. (2010). Conversation and interactional analysis. In L. Wei \& M. G. Moyer (Eds.), The Blackwell guide to research methods in bilingualism and multilingualism (s. 275-296). Oxford: Blackwell Publishing.

Coughlan, P., \& Duff, P. A. (1994). Same task, different activities: Analysis of a SLA task from an activity theory perspective. In J. P. Lantolf \& G. Appel (Eds.), Vygotskian approaches to second language research (s. 173-193). Wesport: Ablex.

Coulmas, F. (1985). Sprache und Staat. Studien zur Sprachplanung. Berlin: De Gruyter.

Cummins, J. (2007). Rethinking monolingual instructional strategies in multilingual classrooms. Canadian Journal of Applied Linguistics, 10(2), 221-40.

Deppermann, A., \& Spranz-Fogasy, T. (2001). Aspekte und Merkmale der Gesprächssituation. In G. Antos, K. Brinker, W. Heinemann, \& S. Sager (Eds.), Text- und Gesprächslinguistik (s. 1148-1161). Berlin: Walter de Gruyter.

Dewaele, J. M., \& Thirtle, H. (2009). Why do some young learners drop foreign languages? A focus on learner-internal variables. International Journal of Bilingual Education and Bilingualism, 12(6), 635-649.

Drew, P., \& Heritage, J. (Eds.). (1992). Analyzing talk at work: An introduction. In P. Drew \& J. Heritage (Eds.), Talk at work: Interaction in institutional settings (s. 3-65). Cambridge: Cambridge University Press. 
Firth, A., \& Wagner, J. (1997). On discourse, communication, and (some) fundamental concepts in SLA research. The Modern Language Journal, 81(3), 285-300.

Fitts, S. (2009). Exploring third space in a dual-language setting: Opportunities and challenges. Journal of Latinos and Education, 82(2), 87-104.

Gafaranga, J. (2007). Code-switching as a conversational strategy. In P. Auer \& L. Wei (Eds.), Handbook of multilingualism and multilingual communication (s. 279-313). Berlin: Mouton de Gruyter.

García, O. (2009). Bilingual education in the 21st Century: A global perspective. Malden: Wiley/ Blackwell.

García, O. (2014). Multilingualism and language education. In C. Leung Brian \& V. Street (Eds.), The Routledge companion to English (s. 84-99). Abingdon: Routledge.

García, O., \& Wei, L. (2014). Translanguaging: Language, bilingualism and education. Houndmills: Palgrave.

Gudjons, H. (2000). Methodik zum Anfassen: Unterrichten jenseits von Routinen. Bad Heilbrunn: Velag Julius Klinkhardt.

Gumperz, J. J. (1964). Linguistic and social interaction in two communities. American Anthropologist, 66(6, Part 2), 137-153.

Gumperz, J. J. (1982). Discourse strategies. New York: Cambridge University Press.

Hall, G., \& Cook, G. (2012). Own-language use in language teaching and learning. Language Teaching, 45(3), 271-308.

Heller, M. (Ed.). (1988). Codeswitching: Anthropological and sociolinguistic perspectives. Berlin: Walter de Gruyter.

Henry, A., \& Apelgren, B. M. (2008). Young learners and multilingualism: A study of learner attitudes before and after the introduction of a second foreign language to the curriculum. System, 36(4), 607-623.

Heritage, J. (2005). Conversation analysis and institutional talk. In K. L. Fitch \& R. E. Sanders (Eds.), Handbook of language and social interaction (s. 103-147). Mahwah: Lawrence Erlbaum Associates.

Heritage, J. (2016). Conversation analysis: Practices and methods. In D. Silverman (Ed.), Qualitative research (s. 207-225). London: Sage.

Hiebert, J., Gallimore, R., Garnier, K., Hollingsworth, J., Jacobs, J., Chui, A. M. Y.,... Stigler, J. (2003). Teaching mathematics in seven countries: Results from the TIMSS 1999 video study. Washington: U.S. Department of Education.

Hufeisen, B. (2011). Gesamtsprachencurriculum: Weitere Überlugungen zu einem prototypischen Modell. In R. S. Baur, S. Rupprecht, \& B. Hufeisen (Eds.), „Vieles ist ähnlich", Individuelle und gesellschaftliche Mehrsprachigkeit als bildungspolitische Aufgabe (s. 256-282). Baltmannsweiler: Schneider Verlag Hohengehren.

Hufeisen, B., \& Neuner, G. (Eds.). (2003). Mehrsprachigkeitskonzept - Tertiärsprachenlernen Deutsch nach Englisch. Strasbourg: Council of Europe Publ.

Christ, H. (1995). Sprachenpolitische Perspektiven. In K.-R. Bausch, H. Christ, \& H.-J. Krumm (Eds.), Handbuch Fremdsprachenunterricht (s. 75-81). Marburg: Francke.

Jacquemet, M. (2005). Transidiomatic practices: Language and power in the age of globalization. Language and Communication, 25, 257-77.

Jakisch, J. (2014). Lehrerperspektiven auf Englischunterricht und Mehrsprachigkeit. Zeitschrift für Interkulturellen Fremd- sprachenunterricht, 19(1), 202-215. 
Janík, T., Slavík, J., Mužík, V., Trna, J., Lokajíčková, V., Lukavský, J., ... Zlatníček, P. (2013). Kvalita (ve) vzdělávání: Obsahově zaměřený př́stup ke zkoumání a zlepšování výuky. Brno: Masarykova univerzita.

Johnson, D. C. (2010). Implementational and ideological spaces in bilingual education language policy. International Journal of Bilingual Education and Bilingualism, 13(1), 61-79.

Jørgensen, J. N. (2008). Polylingual languaging around and among children and adolescents. International Journal of Multilingualism, 5(3), 161-76.

Kaderka, P. (2013). Pragmatika situace. Slovo a slovesnost, 74(1), 13-40.

Kalthoff, H. (2000). Wunderbar, richtig. Zeitschrift für Erziehungswissenschaft, 3(3), 429-446.

Kemmeter, L. (1999). Multilingual gestütztes Vokabellernen im gymnasialen Englischunterricht. Frankfurt am Main: Peter Lang Verlag.

Klieme, E., Eichler, W., Helmke, A., Lehmann, R. H., Nold, G., Rolff, H.-G., ... Willenberg, H. (2006). Unterricht und Kompetenzerwerb in Deutsch und Englisch. Frankfurt am Main: DIPF.

Kloss, H., \& Van Orden, G. (2009). Soft-assembled mechanisms for the grand theory. In J. P. Spencer, M. Thomas, \& J. McClelland (Eds.), Toward a new grand theory of development? Connectionism and dynamics systems theory reconsidered (s. 253-267). Oxford: Oxford University Press.

Kretzenbacher, H. L. (2009). Deutsch nach Englisch: Didaktische Brücken für syntaktische Klammern. Electronic Journal of Foreign Language Teaching, 6(1), 88-99.

Krumm, H.-J. (2003). Sprachenpolitik und Mehrsprachigkeit. In B. Hufeisen \& G. Neuner (Eds.), Mehrsprachigkeitskonzept - Tertiärsprachenlernen - Deutsch nach Englisch (s. 35-49). Strasbourg: Council of Europe Publ.

Krumm, H.-J. (2015). Organisiertes Schulversagen - oder: Anforderungen an die Schule in der Einwanderungsgesellschaft. In İ. Dirim (Ed.), Impulse für die Migrationsgesellschaft. Bildung, Politik und Religion (s. 280-293). Münster: Waxmann.

Krzyżanowski, M., \& Wodak, R. (2011). Political strategies and language policies: The European Union Lisbon strategy and its implications for the EU's language and multilingualism policy. Language Policy, 10(2), 115-136.

Levinson, B. A., Sutton, M., \& Winstead, T. (2009). Education policy as a practice of power theoretical tools, ethnographic methods, democratic options. Educational Policy, 23(6), 767-795.

Lewis, G., Jones, B., \& Baker, C. (2012). Translanguaging: Origins and development from school to street and beyond. Educational Research and Evaluation, 18(7), 641-654.

Lyster, R. (1998). Negotiation of form, recasts, and explicit correction in relation to error types and learner repair in immersion classrooms. Language Learning, 48(2), 183-218.

Makalela, L. (2015). Moving out of linguistic boxes: The effects of translanguaging strategies for multilingual classrooms. Language and Education, 29(3), 200-217.

Markee, N. (2000). Conversation analysis. Mahwah: Lawrence Erlbaum.

Markee, N., \& Kasper, G. (2004). Classroom talks: An introduction. The Modern Language Journal, $88(4), 491-500$.

Mazeland, H. (2006). Conversation analysis. In K. Brown (Ed.), Encyclopedia of language \& linguistics (s. 153-163). Oxford: Elsevier.

McHoul, A. W. (1978). The organization of turns at formal talk in the classroom. Language in Society, 7(2), 183-213. 
McHoul, A. W. (1990). The organization of repair in classroom talk Language in Society, 19(3), 349-377.

McKay, S. L. (2006). Researching second language classroom. New Jersey: Lawrence Erlbaum Associates.

Mehan, H. (1979). Learning lessons. Cambridge: Harvard University Press.

Meißner, F.-J. (2004). Transfer und Transferieren: Anleitungen zum Interkomprehensionsunterricht. In H. G. Klein \& D. Rutke (Eds.), Neuere Forschungen zur Europäischen Interkomprehension (s. 39-66). Aachen: Shaker.

Meyer, H., \& Meyer, M. A. (1997). Lob des Frontalunterrichts: Argumente und Anregungen. Friedrich Jahresheft, $X V, 34-37$.

Mori, J. (2002). Task design, plan and development of talk-in-interaction: An analysis of a small group activity in a Japanese language classroom. Applied Linguistics, 23(3), 323-347.

Münich, D., et al. (2011). Závěrečná zpráva podskupin Národní ekonomické rady vlády pro konkurenceschopnost a podporu podnikání: Kapitola III - Vzdělanost. Praha: NERV. Dostupné z https://www.vlada.cz/assets/media-centrum/aktualne/NERV_kap03.pdf

Najvar, P., Najvarová, V., Janík, T., \& Šebestová, S. (2011). Videostudie v pedagogickém výzkumu. Brno: Paido.

Nekvapil, J., Sloboda, M., Wagner, P., \& Wagner, P. (2009). Mnohojazyčnost v České republice: základní informace. Praha: Nakl. Lidové Noviny.

Neustupný, J. V., \& Nekvapil, J. (2003). Language management in the Czech Republic. Current Issues in Language Planning, 4(3/4), 181-366.

Otsuji, E., \& Pennycook, A. D. (2010) Metrolingualism: Fixity, fluidity and language in flux. International Journal of Multilingualism, 7(3), 240-54.

Palmer, D. K., \& Martínez, R. A. (2016). Developing biliteracy: What do teachers really need to know about language?. Language Arts, 93(5), 379-385.

Rámcový vzdělávací program pro základní vzdělávání. (2007). Praha: MŠMT. Dostupné z http:// www.vuppraha.cz/wp-content/uploads/2009/12/RVPZV_2007-07.pdf

Rámcový vzdělávací program pro základní vzdělávání. (2013) Praha. Dostupné z http://www. msmt.cz/vzdelavani/zakladni-skolstvi/upraveny-ramcovy-vzdelavaci-program-prozakladni-vzdelavani

Reusser, K., \& Pauli, C. (2003). Mathematikunterricht in der Schweiz und in weiteren sechs Ländern. Bericht über die Ergebnisse einer internationalen und schweizerischen VideoUnterrichtsstudie. Zürich: Universität Zürich - Pädagogisches Institut.

Rimmele, R. (2002). Videograph. Multimedia-Player zur Kodierung von Videos. Kiel: IPN.

Seedhouse, P. (2004). The interactional architecture of the language classroom: A conversation analysis perspective. New Jersey: Wiley-Blackwell.

Selting, M., Auer, P., Barth-Weingarten, D., Bergmann, J. R., Bergmann, P., Birkner, K., ... Hartung, M. (2009). Gesprächsanalytisches Transkriptionssystem 2 (GAT 2). Gesprächsforschung Online-Zeitschrift zur verbalen Interaktion, 10, 353-402.

Sert, O., \& Walsh, S. (2013). The interactional management of claims of insufficient knowledge in English language classrooms. Language and Education, 27(6), 542-565.

Schegloff, E. A. (1992). On talk and its institutional occasions. In P. Drew \& J. Heritage (Eds.), Talk at work: Interaction in institutional settings (s. 101-134). Cambridge: Cambridge University Press. 
Schegloff, E. A. (2007). Sequence organization in interaction: A primer in conversation analysis I. Cambridge: Cambridge University Press.

Schütze, F. (1987). Situation. In U. Ammon, N. Dittmar, \& K. J. Mattheier (Eds.), Soziolinguistik (s. 157-164). Berlin: de Gruyter.

Sladkovská, K., \& Šmídová, T. (2010). Podpora vícejazyčnosti v Evropě. Dostupné z http://www. msmt.cz/vzdelavani/zakladni-vzdelavani/podpora-vicejazycnosti-v-evrope

Společný evropský referenční rámec pro jazyky (2002). Rada Evropy. Dostupné z http://www. msmt.cz/mezinarodni-vztahy/spolecny-evropsky-referencni-ramec-pro-jazyky

Stivers, T., \& Robinson, J. D. (2006). A preference for progressivity in interaction. Language in Society, 35(03), 367-392.

Swain, M., Lapkin, S., Knouzi, I., Suzuki, W., \& Brooks, L. (2009). Languaging: University students learn the grammatical concept of voice in French. The Modern Language Journal, 93(1), $5-29$.

Ten Have, P. (2007). Doing conversation analysis. London: Sage.

Tůma, F. (2016). Konverzační analýza a interakce ve tř́dě: východiska a metodologické aspekty. Pedagogická orientace, 26(3), 415-441.

Vetter, E. (2013). Sprachliche Bildung macht den Unterschied. Sprachen in schulischen Lehrkontexten. In E. Vetter (Ed.), Professionalisierung für sprachliche Vielfalt. Perspektiven für eine neue LehrerInnenbildung (s. 238-258). Hohengehren: Schneider.

Vzdělávání, mládež, kultura. (2008). Brusel: Rada evropské unie. Dostupné z http://www. consilium.europa.eu/uedocs/cms_data/docs/pressdata/CS/educ/101414.pdf

Woolard, K. A. (1992). Language ideology: Issues and approaches. Pragmatics, 2(3), 235-249.

Zlatníček, P. (2015). Zjištování kvality výuky cizího jazyka: vývoj a aplikace nástroje pro posuzování míry zastoupení vybraných komponent a charakteristik kvality výuky (Disertační práce). Dostupné z https://is.muni.cz/auth/th/160506/pedf_d_b1/

\section{Autor}

Mgr. Miroslav Janík, Ph.D., Masarykova univerzita, Pedagogická fakulta, Institut výzkumu školního vzdělávání, Poříčí 7/9, 60300 Brno, e-mail: mjanik@ped.muni.cz

\section{How German language teachers use English in their lessons}

Abstract: In this study we have focused on how teachers use English language in
teaching German as a second foreign language (after English). In the theoretical
part, languages and language practices in relation to multilingualism and language
policy are introduced. In this study we understand languages as linguistic repertoire
and multilingualism as the ability to use (at various levels) three or more languages.
Language policy is understood not just on the state level ("top-down") which prefers
to separate languages, but also as language policy based on teachers language 
practices ("bottom-up") which includes permitting languages through their usage. The main research question is how teaching situations are organized in which the teacher's use of English in teaching German is evident. The research sample consisted of video recordings of 28 lessons of German as a foreign language at lower-secondary schools (including their transcripts). Following the introduction of the method of analysis - conversation analysis - and its theoretical background, we define the unit of analysis, i.e. the teaching situation and the process of its identification. In the subsequent part of the study, the research findings are presented. As far as the structure of the identified teaching situations is concerned, it is clear that they mostly follow the initiation - response - feedback (IRF) pattern in various modifications. The analysis suggests that teachers' use of English language in German teaching is mostly present in comments and as part of giving a clue. If the English language was present in a teacher's comment, it usually developed the feedback on pupils' utterance or it served as an explanation, in which the metalinguistic knowledge of languages was supported. Clues in which the English language was evident were usually used as a reaction to a problem or a mistake (often not connected to English language). In such cases the English language was used to provide metalinguistic clues that were meant to help the pupil with self-repair. They suggest that for the teachers using English is a common language practice for developing pupils' German. On the other hand, no systematic approach for using of English and multilingualism development was evident.

Key words: multilingualism, linguistic repertoire, language practice, language policy, foreign language didactics, teaching German after English, conversation analysis, teaching situation, IRF structure 


\section{Příloha 1: Transkripční systém GAT2 (základní verze)}

Sekvenční struktura/struktura v průběhu

[]

[]

$=$

Nádechy a výdechy

${ }^{\circ} \mathrm{h} / \mathrm{h}^{\circ}$

${ }^{\circ} \mathrm{hh} / \mathrm{hh}^{\circ}$

${ }^{\circ} \mathrm{hhh} / \mathrm{hhh}^{\circ}$

Pauzy

$($.

$(-)$

$(--)$

$(---)$

Segmentální konvence

a_ehm

ehm, ahm

Smích a pláč

haha hehe hihi

((smích)) ((pláč))

<<smích $>>$

Recepční signály

hm jo ne nee

hm_hm no_jo

Další konvence

((píše na tabuli))

<<angl. výslovnost > ><smiles>[AlH2]</smiles>

(solche)

(also/alo)
Překryvy a simultánní promluvy

Rychlé nebo přímé napojení promluv

Nádechy a výdechy v trvání 0.2-0.5 sek.

Nádechy a výdechy v trvání 0.5-0.8 sek.

Nádechy a výdechy v trvání 0.8-1.0 sek.

Mikropauza

Krátká pauza

Střední pauza

Delší pauza

Měřená pauza

(přesně měřené údaje)

Hezitační pauza spojená se slovem

Hezitační pauza

Smích ve slabikách

Popis smíchu/pláče

Promluva ve smíchu

Jednoslabičné signály

Dvouslabičné signály

Parajazykové a nejazykové signály a činnosti

Jazykové signály a parajazykové signály spojené s promluvou

Nesrozumitelné pasáže

Pravděpodobné znění

Pravděpodobné alternativy 
$\rightarrow \quad$ Odkaz na řádek, který je tematicky významný

Důraz

důRAZ

Důraz

dů!RAZ!

Extra silný důraz

Melodie hlasu/intonace

?

Melodie silně stoupavá

Melodie mírně stoupavá

Žádná změna v intonaci

Melodie mírně klesavá

Melodie silně klesavá

Jedlička, R. (2017). Psychický vývoj dítěte a výchova: Jak porozumět situačním obtížím. Praha: Grada.

Dětství a mládí jsou klíčová období, která v mnohém zásadně určují následný lidský život. Publikace se zabývá psychickým vývojem dětí už od doby před narozením až do období dospívání. Poukazuje na to, jaké možnosti a limity má výchova v rámci rodiny i školy vzhledem k individuálním zvláštnostem dětí. Autor poutavým způsobem objasňuje, jak výchova ovlivňuje sebepojetí, sociální zařazení a schopnost jedince vyrovnávat se $s$ těžkostmi. Díky terapeutické praxi a mnohaletým zkušenostem s výukou na vysoké škole dokáže srozumitelně vyložit př́íciny emočních problémů, dynamiku duševních poruch i pozoruhodné výsledky výzkumů. Prostřednictvím případových studií seznamuje čtenáře s řešením výchovných obtíží, ale také s důsledky toho, když nebyla dětem či dospívajícím v krizi poskytnuta potřebná podpora. Odborné pojednání o vývoji dítěte a mladého člověka nepochybně uvítají nejen vysokoškolská pracoviště připravující do praxe budoucí učitele, psychology, zdravotníky a sociální pracovníky, ale najde uplatnění i v programech celoživotního vzdělávání pro odborníky pomáhajících profesí. 